\title{
The Effect of Liquidity on Financial Performance: Evidence from Turkish Retail Industry
}

\author{
Kartal Demirgüneş $^{1}$ \\ ${ }^{1}$ Faculty of Economics and Administrative Sciences, Ahi Evran University, Kırşehir, Turkey \\ Correspondence: Kartal Demirgüneş, Faculty of Economics and Administrative Sciences, Ahi Evran University, \\ Kırşehir, Turkey. Tel: 90-386-280-4926. E-mail: kartal.demirgunes@ ahievran.edu.tr
}

Received: February 18, 2016

Accepted: March 7, 2016

Online Published: March 25, 2016

doi:10.5539/ijef.v8n4p63

URL: http://dx.doi.org/10.5539/ijef.v8n4p63

\begin{abstract}
The aim of this study is to analyse the effect of liquidity on financial performance (in terms of profitability) by using a time-series data of Turkish retail industry (consisting of Borsa Istanbul (BIST) listed retail merchandising firms) in the period of 1998.Q1-2015.Q3. The stationarity of series and the co-integration relationship between them are tested by the unit root test of Carrioni-i-Silvestre et al. (2009) and the co-integration test of Maki (2012), respectively. Co-integration coefficients are estimated by Stock and Watson (1993) dynamic OLS method. Finally, causal relationships between the series are tested by Hacker and Hatemi (2012) bootstrap causality test. Results of Maki (2012) test show that the series are co-integrated in the long-run. While long-run parameters estimated posit a significantly positive relationship between financial performance and liquidity, causality test does not indicate any direction of causality between the series.
\end{abstract}

Keywords: financial performance, liquidity, multiple structural breaks unit root test, multiple structural breaks co-integration test, dynamic OLS, bootstrap causality test

\section{Introduction}

Studies on the determinants of financial performance (in terms of profitability) have attracted enormous research attention in various research traditions such as economics, management, accounting and finance. Most of this research is based on the traditional structure-conduct-performance paradigm of Bain (1959) that focuses on industry characteristics such as concentration, economies of scale, and entry and exit barriers (Goddard et al., 2005). This paradigm is a model in industrial organization economics offering a causal theoretical explanation for firm performance, suggesting that firm's (financial) performance depends on its conduct, which in turn depends on structural factors (Pattitoni et al., 2014). In the strategic management literature, the determinants of (variations in) performance in terms of profitability are associated with the firm-specific internal resources. According to the resource based view, the primary determinants of firm performance are the resources (such as all assets, capabilities, organizational processes, information, knowledge, etc.) possessed by a firm. These resources may not only contribute to a sustainable competitive advantage of the firm (Wernerfelt, 1984), but also enable the firm to implement strategies that improve its efficiency and effectiveness (Daft, 1983; Barney, 1991). Finally, accounting and finance literature includes a separate but related strand of research concerning the usefulness of the random walk model as a descriptor of time series movements in firm profitability. Here, by the random walk model it is meant that growth of earnings (profitability) of firms evolves according to a random walk and therefore cannot be predicted (See, Little, 1962; Ball \& Watts, 1972; Callen et al., 1993; Fama \& French, 2002; Chan et al., 2003).

Among these research traditions, while economics -mostly focusing on the competition existing in the marketstries to explain firm performance as an indirect effect of structural factors; strategic management, accounting and finance consider firm-specific internal resources as primary determinants of firm performance (Jensen, 1986; Stulz, 1990; Barney, 1991-2001). According to Capon et al. (1990), typical firm-specific internal resources (may also be referred as micro-level variables) are liquidity, size, growth and leverage.

Although there are so many empirical studies on the determinants of financial performance, a great majority of them are related to manufacturing industries (and/or manufacturing firms). Though the studies of Kamath (1989) on large firms in six retail industries in the United States, Phillips and Sipahioglu (2004) on hotels in United Kingdom, Amato and Amato (2004) on commercial retail firms in the United States, Goddard et al. (2005) on 
various sub-sectors of the service industries in some selected European countries, Galbreath and Galvin (2008) on various sub-sectors of the Australian service industries, Nunes et al. $(2009 ; 2010)$ on Portuguese service industries and service SMEs, Topal et al. (2013) on supermarket chains in Turkey, Mun and Jang (2015) on restaurant firms in the United States, and Özçelik and Kandemir (2015) on Borsa İstanbul listed tourism firms are exceptions; it is obvious that the empirical studies on the determinants of financial performance of service industries (and/or service firms) (Note 1) and especially of the retail industry (and/or retail firms) are somehow neglected. This study aims to fill this gap by focusing on the effect of liquidity on financial performance in Turkish retail industry. Throughout this aim, advanced econometric methods are performed to estimate the mentioned effect on a sample of Turkish retail industry, consisting of Borsa Istanbul (BIST) listed retail merchandising firms, for the period of 1998.Q1-2015.Q3. In the following section of the study, an overview of Turkish retail industry and related literature review are presented, respectively. Subsequently, methodology and empirical results are given. Finally, in the Conclusion, significant findings are discussed, limitations of the study and suggestions for further studies are presented.

\section{A Brief Overview of Turkish Retail Industry}

Till the beginning of 1980s, Turkey's development strategy was based on import-substituting industrialization under the tight control of a both publicly and privately-owned but state-dependent industrial sector, showing little responsiveness to international changes (Tokatlı \& Boyac1, 1998). The business environment was strictly protected and directed to internal markets, and there were barriers to foreign direct investments. However, beginning from the mid-1980s, Turkey has witnessed a rapid and remarkable transformation in almost every aspect, due to economic restructuring as a result of more liberal, more market-oriented and more outward-looking policies. This transformation also prepared a base for the enormous development of retail industry in Turkey. Before this transformation, the retail trade was mostly under the control of small-scale, capital-weak, independent and family-owned retailers (Kaynak, 1986), and it might not be possible to discuss any form of integration among them, neither horizontally nor vertically (Kumcu \& Kumcu, 1987).

Retail development in Turkey can be discussed in two periods. The first period between 1990 and 2000 has witnessed the rise of shopping malls, especially in large cities. In the second period between 2000 and 2010, these malls have evolved into more complex marketspaces, and shopping mall investments have extended to smaller cities (Erkip \& Özüduru, 2015). The timing of these periods may be associated with economic liberalization policies and -of course- global trends. The first stimuli in the first period came from Western Europe by the development of production and distribution techniques and the direct investments of European multinational retailers (Özcan, 2000, p. 106). The investments of Carrefour, Metro, Real, Marks \& Spencer and Makro can be given as examples. The second stimuli came in the late-1990s by capital concentration through both domestic and foreign retailers. Leading large holding companies such as Koç Group, Sabancı Group and Doğuş Group, etc. have established partnerships with both domestic and foreign retailers. The growing interest of foreign investors in local retailers, the increasing share of international capital in Turkey, and the mentioned partnerships have triggered the extension of malls and the development of retail industry in Turkey. Additionally, increases in the average income and financial support of consumption through bank credits and credit cards (Erkip, 2005), changes in communication strategies including publicity and personalized advertising (Erdil et al., 2014), changes in technology (the internet, computer applications to business, just-in-time delivery systems, etc.), changes in consumers' demographics (increases or decreases in population figures, age groups, racial groups, socio-economical groups, etc.), changes in lifestyle (whereby time is important and therefore fast-food, e-banking, credit card payments and having private cars are gaining importance), and changes in competition (Gilbert, 2003) had remarkable contributions to this development.

Though the retail development in Turkey may be interrupted by international and domestic economic and financial crises by many times (such as Gulf Crisis in 1990, Currency Crisis in 1994, the financial crises of 1998, November 2000 and February 2001, and Global Credit Crunch in 2008); the related indicators of Turkish economy show that the consumption patterns have tendency to persist (See, Table 1). Since the early 2000s, due to resolutely implemented structural reforms and successful macroeconomic policies, Turkey has become one of the fastest-growing economies in its region. Between 2004 and 2014, gross domestic product (GDP) increased by $105 \%$, reaching USD 800 billion (with annual average real GDP growth of $4.2 \%$ ); public debt stock decreased from $74 \%$ of GDP to $33.5 \%$ of GDP; and budget deficit decreased from $10 \%$ of GDP to $0.8 \%$ of GDP. Gross national income (formerly, gross national product) per capita increased from $\$ 2,300$ up to $\$ 10,830$ and merchandise trade as a percentage of GDP grew up to 50.08 between 1990 and 2014. Also, foreign direct investment (FDI) inflow to Turkey has increased remarkably since the 1990s. According to the TUIK's income distribution data, while the share from the total income of the first four groups of $20 \%$ starting from the very 
poor increased after the year 2000, the share of the richest $20 \%$ showed a constant decline. Besides, while the share of the first $20 \%$ who received the least share from total income was $5.3 \%$ in 2002, this figure went up to $6.6 \%$ in 2013. The share of the fifth group who received the biggest share from total income was $50 \%$ in 2002 , while this went back to $45.2 \%$ in 2013. In parallel with this, the Gini coefficient, an indicator of the inequality in income distribution, was 0.44 in 2002 and went back to 0.39 in 2014, creating an impression that distribution has entered a recovery process.

The total population in Turkey was last recorded at 77.7 million people in 2014 from 54.0 million in 1990, changing nearly $44 \%$ during the last 25 years. Though life expectancy at birth has increased globally by 6 years since 1990, the increase in Turkey became twice of it. With a yearly population growth rate of $1.22 \%$ in 2014, Turkey lies above both the world's and the European averages. Turkey ranked $72^{\text {th }}$ out of 188 countries on the human development index (HDI) with a value of 0.761 , putting it in the "high human development" category for 2015. In the report of year 2014, Turkey ranked $69^{\text {th }}$ out of 187 countries, with a HDI value of 0.759 . Turkey has jumped 16 ranks over the past five years, making it the country registering the highest progress in the Eastern Europe and Central Asia region.

While mobile cellular subscriptions (per 100 people) in Turkey was measured at only 25.54 in 2000, this figure went up to 94.80 in 2014, according to the World Bank Data. At the end of the $3^{\text {rd }}$ quarter of 2015, there were 73.2 million mobile cellular subscribers in Turkey. While, Turkey had 35 million internet users in 2010, this increased to 41 million internet users in 2014. This figure is projected to grow to 56 million internet users in 2019. Increases in the number of mobile cellular subscribers and internet users have increased exposure to other cultures, constituting the basis of a new consumer type under the influence of global consumption patterns (Erkip, 2005), therefore triggering the retail development.

Table 1. Some selected Indicators of Turkish economy

\begin{tabular}{lccccccccc}
\hline Indicator & 1990 & 2000 & 2008 & 2009 & 2010 & 2011 & 2012 & 2013 & 2014 \\
\hline GDP growth (annual \%) & 9.27 & 6.77 & 0.66 & -4.83 & 9.16 & 8.77 & 2.13 & 4.19 & 2.91 \\
GNI per capita (current int. \$) & 2,300 & 4,190 & 9,340 & 9,130 & 9,950 & 10,490 & 10,800 & 10,970 & 10,830 \\
Gini coefficient & NA & NA & 0.383 & 0.390 & 0.388 & 0.400 & 0.402 & 0.400 & 0.391 \\
Merchandise trade (\% of GDP) & 23.40 & 30.87 & 45.73 & 39.55 & 40.95 & 48.50 & 49.31 & 49.01 & 50.08 \\
FDI, net inflows (millions, current US\$) & 684 & 982 & 19,851 & 8,585 & 9,099 & $1,617.6$ & 13,282 & 12,547 & 12,765 \\
Total population (millions) & 53.995 & 63.240 & 70.344 & 71.261 & 73.723 & 74.724 & 75.627 & 76.668 & 77.696 \\
Population growth (\%) & 1.73 & 1.51 & 1.19 & 1.30 & 1.46 & 1.22 & 1.22 & 1.22 & 1.22 \\
Urban population growth (\%) & 3.96 & 2.31 & 2.03 & 2.12 & 2.28 & 2.02 & 1.99 & 1.97 & 1.94 \\
Life expectancy at birth (years) & 64.28 & 69.99 & 73.53 & 73.88 & 74.21 & 74.54 & 74.86 & 75.19 & 76.30 \\
Human development index (HDI) & 0.569 & 0.645 & 0.806 & 0.679 & 0.715 & 0.720 & 0.722 & 0.759 & 0.761 \\
Mobile cellular subscribers (per 100 people) & 0.06 & 25.54 & 93.55 & 88.12 & 85.63 & 89.41 & 91.46 & 92.97 & 94.80 \\
Internet users (per 100 people) & 0 & 3.76 & 34.37 & 36.40 & 39.82 & 43.07 & 45.13 & 46.25 & 51.04 \\
\hline
\end{tabular}

Source: TUIK Databases, The World Bank Databases, UNDP Human Development Reports, OECD Factbooks. (NA: not available).

As implied by the above mentioned economic indicators, Turkey's growth and its continuing long term potential continue to attract both domestic and foreign investors worldwide. In accordance with the economic growth, the Turkish retail industry is one of the most appealing sectors for both investors and consumers. This reality is also reflected by retail sales figures of Turkish retail industry (see, Table 2). Turkish consumers' attitude towards shopping has spurred the sector, encouraging a number of global brands such as Pernigotti, Eleven Paris, Anta and Freddy, and Under Armour etc. to enter the market. In this context, while the consumer confidence index hit 76.04 in 2014, the retail trade confidence index hit 108.20 and 105.83 in 2011 and in 2013, respectively. By the end of 2013, the total size of retail sector in Turkey has reached US $\$ 303$ billion. Besides, between 2014 and 2018 , the sector is expected to grow with a compound annual growth rate of c. $7 \%$. This relatively high expectation is supported with the increasing number and size of shopping malls and total leasable areas, and with the increased credit card use among Turkish consumers. According to data released by Turkey's Interbank Card Center, the total value of credit/debit card transactions increased by $21 \%$ year-over-year while compound annual growth rate for the last five years is c. 15\% in 2012. In the same year, 19 million out of the existing 54 million credit cards in Turkey have been used for online shopping, and the number of credit cards issued by banks has risen by $6 \%$ during the year, while the number of debit cards issued has increased by $11 \%$, amounting to 91 million. 
Table 2. Turkish retail industry facts

\begin{tabular}{lrrrrrrrrrr}
\hline & 2009 & 2010 & 2011 & 2012 & 2013 & 2014 & 2015 & 2016 & 2017 & 2018 \\
\hline Retail sales (US\$ billion) & $235^{\mathrm{A}}$ & $275^{\mathrm{A}}$ & $284^{\mathrm{A}}$ & $290^{\mathrm{A}}$ & $303^{\mathrm{A}}$ & $250^{\mathrm{F} *}$ & $301^{\mathrm{F}}$ & $325^{\mathrm{F}}$ & $353^{\mathrm{F}}$ & $373^{\mathrm{F}}$ \\
Consumer confidence index & NA & NA & NA & 75.64 & 76.04 & 72.53 & 66.27 & NA & NA & NA \\
Retail trade confidence index & NA & NA & 108.20 & 103.83 & 105.82 & 104.33 & 102.78 & NA & NA & NA \\
\hline
\end{tabular}

(*) Slight decrease in 2014 is due to a forecasted devaluation of $14 \%$ in average TL/US\$ y-o-y. Sector is estimated to grow by $10 \%$ in 2014 by TL based sales.

Source: Deloitte Retail Sector Update (July 2014), The Economist Intelligence Unit (EIU) Turkey Consumer Goods Reports, TUIK Databases. (NA: not available)

A: Actual, F: Forecast.

\section{Literature Review}

Decisions regarding the management of assets should not conflict with the primary objective of the firm: to maximize shareholder wealth. A very essential part of this asset management is the determination of an optimal level of liquidity. Referring to the ability of a firm to meet its short term obligations, liquidity plays a central role in its successfully functioning as a profitable firm. Thus, indicators of liquidity and profitability have major importance to both shareholders and potential investors. In theory, liquidity and profitability goals are generally assumed to be contradictory to each other. The goal of liquidity management should be to enable a firm to maximize profits of its operations while meeting both short term debt and upcoming operational expenses, i.e. to preserve liquidity (Panigrahi, 2014, p. 308). To achieve this goal, the firm should eliminate the risk of inability to meet its short term obligations on one hand, while avoiding excessive investments in current assets on the other hand (Eljelly, 2004). Excessive investments in liquidity may lead managers to make investments towards maximizing their own utility, thus to the detriment of profitability (Fama \& Jensen, 1983). In such circumstances, another pitfall is the managers' tendency to invest in projects with negative net present values (Adams, 1996; Adams \& Buckle, 2003). From this point of view, the trade-off between liquidity and profitability has been an important field of study in corporate finance. This trade-off may be much more important for especially retail firms, as they can be expected to differ significantly in financial characteristics from manufacturing firms. Retail firms tend to have higher liquidity and turnover ratios, lower profitability on sales, and shorter cash conversion and operating cycles compared to manufacturing firms. Besides, having proportionally more current assets and proportionally less fixed assets, retail firms have different asset structures (Gombola \& Ketz, 1983, pp. 46-47). As mentioned before, though it is obvious that the trade-off between liquidity and profitability has been extensively discussed in the literature, the number of empirical studies analyzing this trade-off in the retail industry (or firms) is very limited.

Liquidity management is mostly evaluated from the perspective of working capital management, as most of the indicators used for evaluating liquidity (such as liquidity ratios and cash conversion cycle) are derived from the components of working capital. Thus, it is possible to review the literature regarding the effect of liquidity on profitability from two perspectives. While in some studies, liquidity ratios -considering cash and near-cash (current) assets, and current liabilities in the form of current, acid-test (or quick) and cash ratios- are used to evaluate the effect of liquidity on profitability; the others focus on cash conversion cycle as the main indicator of liquidity. Liquidity ratios capture financial aspects of a firm covering current assets and current debts. However, cash conversion cycle reflects only the operational side of the firm concentrating on accounts receivables, accounts payables and inventories (Mun \& Jang, 2015, p. 2).

The current ratio is the most wide-spread liquidity indicator by deriving the proportion of current assets available to cover current liabilities. The empirical findings from the studies of Sur et al. (2001) on Indian aluminum manufacturing industry, Bardia (2004) on Indian steel manufacturing industry, Eljelly (2004) on a sample of joint stock firms in Saudi Arabia, Lyroudi et al. (1999) on London Stock Exchange listed manufacturing firms, Narware (2004) on the fertilizer industry of India, and Saldanlı (2012) on Turkish manufacturing firms reveal that liquidity in terms of current ratio has statistically negative effect on profitability. Though these evidences support the theory, some empirical findings contradictory to the theory also exist. According to the studies of Ghosh and Maji (2003) on cement and tea industries in India, Muhammad et al. (2012) on textile industry in Pakistan, Ehiedu (2014) on Nigerian Stock Exchange listed manufacturing firms, and Rehman et al. (2015) on Saudi Stock Exchange listed firms, liquidity in terms of current ratio has statistically positive effect on profitability. However, in studies of Singh and Pandey (2008) on Hindalco Industries Limited, Afeef (2011) on Karachi Stock Exchange listed manufacturing firms, Sur and Chakraborty (2011) on selected multinational firms 
in the Indian pharmaceutical industry, Alavinasab and Davoudi (2013) on Tehran Stock Exchange listed firms, and Afonina and Chalupsky (2014) on the high-tech firms in the Visegrad Four (V4) countries, no statistically significant relationship has been found between current ratio and profitability.

The acid-test ratio as a more conservative indicator of liquidity is the proportion of only the most liquid current assets to the amount of current liabilities. It considers only the current assets that will turn to cash quickly such as cash, cash equivalents, short-term marketable securities, and accounts receivables excluding inventories, supplies, and prepaid expenses. While Lyroudi et al. (1999) reveals that liquidity in terms of acid-test ratio has statistically negative effect on profitability, findings from the studies of Singh and Pandey (2008) and Bhayani (2010) on Indian cement industry indicate opposite results. Besides, Afonina and Chalupsky (2014), Ehiedu (2014) and, Rehman et al. (2015) point out that there exists no statistically significant relationship between the mentioned variables.

Ignoring inventory and accounts receivables in total current assets, cash ratio is the most conservative of all the liquidity indicators. However, this ratio is mostly used in the empirical studies regarding efficiency of financial services industry. According to studies of Meder Çakır and Küçükkaplan (2009) on Borsa İstanbul listed manufacturing firms, and Niresh (2012) on selected manufacturing firms in Sri Lanka cash ratio affects profitability negatively. On the contrary, findings of Sinku (2013)'s study on steel industry in India indicate a positive relationship between cash ratio and profitability. Apart from these, Khaldun and Muda (2014) reveals that no significant relationship exists between cash ratio and profitability.

The other indicator used to evaluate liquidity management in some studies is the Cash Conversion Cycle (CCC), also called the Cash-to-Cash Cycle. As an overall indicator of liquidity risk entailed by growth, it is a combination of three cash flow metrics: days of sales outstanding, days of inventory outstanding and days of payables outstanding, respectively (Kroes \& Manikas, 2014, p. 38). CCC is calculated as the sum of the first two metrics minus the last one; and it represents the time period required to convert cash investments in supplies into cash receipts from customers for goods or services rendered. Relatively short cash conversion cycle is generally associated to operational efficiency, therefore to higher profitability, as the extension of the cycle may require additional external financing.

The empirical literature on the effect of cash conversion cycle as liquidity indicator on profitability has yielded mixed results, similar to the literature on the effect of liquidity ratios on profitability. The common empirical finding from the studies of Jose et al. (1996), Shin and Soenen (1998), Churchill and Mullins (2001), Farris and Hutchison (2002), Wang (2002), Garcia-Teruel and Martinez-Solano (2007), Şamiloğlu and Demirgüneș (2008), Randall and Farris (2009), Dong and Su (2010), Banos-Caballero et al. (2014) indicates that efficient liquidity management in terms of lower CCC is associated with higher profitability. Although very few in number, in contrast to predictions, some researchers such as Kamath (1989), and Gill et al. (2010) find that longer cash conversion cycle is associated with higher profitability.

\section{Methodology}

\subsection{Data, Variables and the Model}

The data of the study covers 1998.Q1-2015.Q3 for the Turkish retail industry, consisting of BIST listed retail merchandising firms. Throughout the aim of the study, three variables are included in the model: profitability as the dependent, and liquidity and growth as the independent variables. In empirical studies, it is obviously seen that the variables may be measured in different ways due to the aim and context of the studies involved.

In this study, the most common measure of profitability (for a detailed literature, see Al-Matari et al., 2014), i.e. return on assets is used as the dependent variable of the model to refer profitability. Though in some studies of Ebaid (2009), Ferati and Ejupi (2012), Velnampy and Niresh (2012), Bokhari and Khan (2013), Topal et al. (2013), and Kaya (2014), return on equity has been used as profitability measure, it can be emphasized that this measure is more appropriate to be referred in studies related to -especially- financial service firms/industries. Besides, return on assets measure gives a quick indication of the capital intensity and assets utilization depending on the industry, and overcomes variations based on size in terms of total profits (Demirgüneş \& Üçler, 2015, p. 683).

The independent variable of the model regarding liquidity is the current ratio. Cash conversion cycle is not included in the model, as it is intended to capture the financial aspects (performance) of retail industry, rather than focusing on the operational side of the industry. Besides, as seen in the Literature Review, current ratio is the most wide-spread liquidity indicator. Another factor on the persistence of current ratio is the financial characteristics of the retail industry. The retail industry, purchasing goods on cash basis or on credit basis for a 
relatively short period and selling to consumers quickly compared to manufacturing industry, requires higher current ratio. Therefore, current ratio as a measure of liquidity is assumed to be superior to working capital related liquidity measures such as cash conversion cycle and/or operating cycle. The other independent variable included in the model is the sales' growth variable as used in most of related studies (see, Weinzimmer et al., 1998; Coad, 2007; Short et al., 2009; Bottazzi et al., 2010; Jang \& Park, 2011). Sales' growth data is easy to obtain from financial statements. Besides, it is a crucial indicator reflecting both short-term and long-term changes in sales capacity of the industry.

Definitions and calculations about the variables of the study are summarized in Table 3.

The regression equation to test possible relationships between profitability, liquidity and growth, is as given below:

$$
R O A_{t}=\beta_{0}+\beta_{1} C U R_{t}+\beta_{2} G R O W_{t}+\varepsilon_{t}
$$

Table 3. Variables

\begin{tabular}{ccc}
\hline Variable Name & Calculation & Symbol \\
\hline Profitability (Return on Assets) & Net Income / Total Assets & ROA \\
Liquidity (Current Ratio) & Current Assets / Current Liabilities & CUR \\
Growth (Sales' Growth) & {$\left[\right.$ Sales $_{\mathrm{t}}-$ Sales $\left._{\mathrm{t}-1}\right] /$ Sales } & \\
$\mathrm{t}-1 \mathrm{H}$ & GROW \\
\hline
\end{tabular}

\subsection{Empirical Findings}

This study aims to find out the possible effect of liquidity on profitability by using some empirical analyses including the multiple structural breaks unit root test of Carrioni-i-Silvestre et al. (2009), multiple structural breaks co-integration test of Maki (2012), Stock and Watson (1993) dynamic ordinary least squares (DOLS) method and bootstrap causality test developed by Hacker and Hatemi-J (2012), respectively.

\subsubsection{Multiple Structural Breaks Unit Root Test of Carrion-i-Silvestre et al. (2009)}

The conventional unit root tests' results may sometimes be misleading when major events like economic crises, wars, catastrophes, etc. have influences on the data to be analyzed, creating structural breaks in the series. As the existence of such breaks may cause these tests to lose their power, the researchers have focused on improving the power of unit root tests by allowing for structural breaks. In the pioneering study of Perron (1989), unit root tests allowing the possibility of a break under null hypothesis of unit against alternative of stationarity are suggested. However, a clear limitation of these tests is the assumption of that the break date is known a priori. Though Zivot and Andrews (2002) have developed alternative unit root test allowing unknown structural breaks, this test and its descendants lose their explanatory powers when a break occurs in the trend function, as they do not allow a break under the null hypothesis. Following, Kim and Perron (2009) have suggested a new methodology allowing a break in the trend function at an unknown time under both the null and the alternative hypotheses. Finally, seeing their test as an extension of Kim and Perron (2009)'s work, Carrioni-i-Silvestre et al. (2009) have developed a multiple structural breaks unit root test. This advanced test allows for the multiple (maximum up to five) breaks in the level and the slope of the trend function both under the null and the alternative hypotheses, adopting the so-called quasi-generalized least squares (quasi-GLS) detrending method advocated by Elliot et al. (1996); and considering the class of M-tests introduced in Stock (1999) and analyzed in Ng and Perron (2001).

In Carrion-i-Silvestre et al. (2009)'s model, $y_{t}$ is the stochastic process generated according to:

$$
\begin{gathered}
y_{t}=d_{t}+u_{t} \\
u_{t}=\alpha u_{t-1}+v_{t}, t=0, \ldots, T
\end{gathered}
$$

where $\left\{\mathrm{u}_{\mathrm{t}}\right\}$ is an unobserved mean-zero process. It is assumed that $u_{0}=0$. The disturbance term $v_{t}$ is defined by $v_{t}=\sum_{i=0}^{\infty} \gamma_{i} \eta_{t-i}$ with $\sum_{i=0}^{\infty} i\left|\gamma_{i}\right|<\infty$ and $\left\{\eta_{t}\right\}$ a martingale difference sequence adopted to the filtration $F_{t}=\sigma$-field $\left\{\eta_{t-1} ; i \geq 0\right\}$. The short-run and long-run variance are defined as $\sigma^{2}=\sigma_{\eta}^{2} \gamma(1)^{2}$ and $\sigma_{\eta}^{2}=\lim _{T \rightarrow \infty} T^{-1} \sum_{t}^{T} E\left(\eta_{t}^{2}\right)$, respectively.

Totally five test statistics have been developed by Carrioni-i-Silvestre et al. (2009) as given in Equations (4) and (7-10). The first one is based on the analyses of Elliot et al. (1996) and Perron and Rodriguez (2003). Here the feasible point optimal statistic is given by:

$$
P_{T}^{G L S}\left(\lambda^{0}\right)=\left\{S\left(\bar{\alpha}, \lambda^{0}\right)-\bar{\alpha} S\left(1, \lambda^{0}\right)\right\} / s^{2}\left(\lambda^{0}\right)
$$


where $s^{2}\left(\lambda^{2}\right)$ is an estimate of the spectral density at frequency zero of $v_{t}$. Following Perron and $\mathrm{Ng}(1998)$ and $\mathrm{Ng}$ and Perron (2001), Carrioni-i-Silvestre et al. (2009) use an autoregressive estimate defined by:

$$
s\left(\lambda^{0}\right)^{2}=s_{e k}^{2} /\left(1-\sum_{j=1}^{k} \hat{b}_{j}\right)^{2}
$$

where $s_{e k}^{2}=(T-k)^{-1} \sum_{t=k+1}^{T} \hat{e}_{t, k}^{2}$ and $\left\{\hat{b}_{j}, \hat{e}_{t, k}\right\}$ obtained from the ordinary least squares (OLS) regression:

$$
\Delta \tilde{y}_{t}=b_{0} \tilde{y}_{t-1}+\sum_{j=1}^{k} b_{j} \Delta \tilde{y}_{t-j}+e_{t, k}
$$

with $\tilde{y}_{t}=y_{t}-\widehat{\Psi}^{\prime} z_{t}\left(\lambda^{0}\right)$ where $\widehat{\Psi}$ minimizes the objective function.

In selection of the order of autoregression $k$, the modified information criteria suggested by $\mathrm{Ng}$ and Perron (2001) and with the modification proposed by Perron and Qu (2007) is used.

Carrioni-i-Silvestre et al. (2009) uses three $M$-class of tests allowing for multiple structural breaks. These are defined by Equations (7-9).

$$
\begin{gathered}
M Z_{\alpha}^{G L S}\left(\lambda^{0}\right)=\left(T^{-1}-s\left(\lambda^{0}\right)^{2}\right)\left(2 T^{-2} \sum_{t=1}^{T} \tilde{y}_{t-1}^{2}\right)^{-1} \\
M S B^{G L S}\left(\lambda^{0}\right)=\left(s\left(\lambda^{0}\right)^{-2} T^{-2} \sum_{t=1}^{T} \tilde{y}_{t-1}^{2}\right)^{\frac{1}{2}} \\
M Z_{t}^{G L S}\left(\lambda^{0}\right)=\left(T^{-1} \tilde{y}_{T}^{2}-s\left(\lambda^{0}\right)^{2}\right)\left(4 s\left(\lambda^{0}\right)^{2} T^{-2} \sum_{t=1}^{T} \tilde{y}_{t-1}^{2}\right)^{-\frac{1}{2}}
\end{gathered}
$$

with $\tilde{y}_{t}=y_{t}-\widehat{\Psi}^{\prime} z_{t}\left(\lambda^{0}\right)$, where $\widehat{\Psi}$ minimizes the objective function, and $s\left(\lambda^{0}\right)^{2}$ is defined in Equation (5).

The fifth statistic in Carrioni-i-Silvestre et al. (2009) is a modified feasible point optimal test defined by:

$$
M P_{T}^{G L S}\left(\lambda^{0}\right)=\frac{\left[c^{-2} T^{-2} \sum_{t=1}^{T} \tilde{y}_{t-1}^{2}+(1-\bar{c}) T^{-1} \tilde{y}_{T}^{2}\right]}{s\left(\lambda^{0}\right)^{2}}
$$

Carrioni-i-Silvestre et al. (2009) obtain asymptotic critical values by using the bootstrap. The null hypothesis of a unit root is rejected in case of calculated test statistics being smaller than critical values. In this situation, it can be said that series is stationary under the presence of structural break. Results of unit root test of Carrioni-i-Silvestre et al. (2009) are given in Table 4.

Table 4. Results of Unit Root Test of Carrion-i-Silvestre et al. (2009)

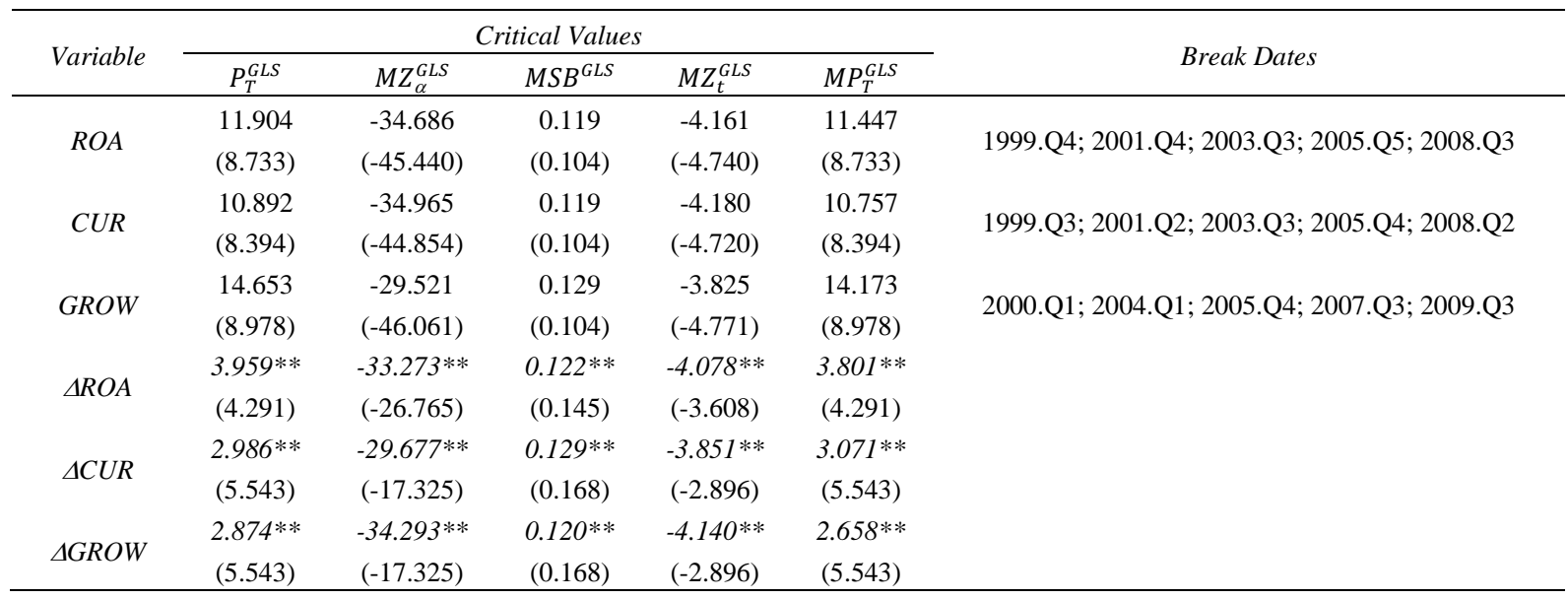

Note. Figures in parenthesis are critical values obtained by using the bootstrap at significance level of $5 \%$. ** and $\Delta$ denote stationarity at significance level of $5 \%$; and the first difference, respectively.

Empirical results indicate that the null hypothesis of a unit root test is accepted, as the calculated test statistics at level are bigger than critical values. Test results also indicate that series are stationary at their first differences and integrated of order one, I(1). Structural break dates estimated will be discussed in the Conclusion part of the study.

4.2.2 Multiple Structural Breaks Co-Integration Test of Maki (2012)

The conventional co-integration tests do not consider the existence of structural breaks in the data, so they may provide biased results while testing for long term relationships. To avoid this, some advanced tests considering 
the existence of structural break(s) have been suggested. Among them, tests suggested by Zivot and Andrews (1992), Gregory and Hansen (1996), Carrioni-i-Silvestre and Sanso (2006), Westerlund and Edgerton (2006), and Hatemi-J (2008) allow only a single structural break. This allowance is criticized by Gregory and Hansen (1996) that in case of referring such tests, breaks may cause spurious unit root behavior in the co-integrating relationship. Thus, multiple (at least more than one) structural breaks should be processed in co-integration tests.

In this context, Maki (2012) proposes a test performing better than its ancestors that allows multiple (maximum up to five) structural breaks. In the algorithm of his test, every period is assumed to be a possible break point and t-statistics for each period is computed; then periods with the lowest t-statistics are determined as break points (Katırcioğlu, 2014). Maki (2012) tries to identify the long-run relationships between series by proposing four different regression models as given in Equations 11-14. Model 1 is with break in intercept and without trend; Model 2 is with break in intercept and coefficients, and without trend; Model 3 is with break in intercept and coefficients, and with trend, and Model 4 is with break in intercept, coefficients, and trend.

$$
\begin{gathered}
y_{t}=\mu+\sum_{i=1}^{k} \mu_{i} D_{i, t}+\beta^{\prime} x_{t}+\mu_{t} \\
y_{t}=\mu+\sum_{i=1}^{k} \mu_{i} D_{i, t}+\beta x_{t}+\sum_{i=1}^{k} \beta_{i}^{\prime} x_{t} D_{i, t}+\mu_{t} \\
y_{t}=\mu+\sum_{i=1}^{k} \mu_{i} D_{i, t}+\gamma+\beta x_{t}+\sum_{i=1}^{k} \beta_{i}^{\prime} x_{t} D_{i, t}+\mu_{t} \\
y_{t}=\mu+\sum_{i=1}^{k} \mu_{i} D_{i, t}+\gamma t+\sum_{i=1}^{k} \gamma_{i} t D_{i, t}+\beta_{i}^{\prime} x_{t}+\sum_{i=1}^{k} \beta_{i}^{\prime} x_{t} D_{i, t}+u_{t}
\end{gathered}
$$

where $t=1,2, \ldots, T . y_{t}$ and $x_{t}=\left(x_{t} \ldots x_{m t}\right)^{\prime}$ denote observable 1(1) variables, and $u_{t}$ is the equilibrium error. $y_{t}$ is a scalar and $x_{t}=\left(x_{1 t}, \ldots, x_{m t}\right)^{\prime}$ is an $(m \times 1)$ vector. It is assumed that an $(n \times 1)$ vector $z_{t}$ is generated by $z_{t}=\left(y_{t}, x_{t}^{\prime}\right)^{\prime}=z_{t-1}+\varepsilon_{t}$, where $\varepsilon_{t}$ are independent identically distributed with mean zero, definite variance-covariance matrix $\Sigma$, and $E\left|\varepsilon_{t}\right|^{s}<\infty$ for some $s>4 . \mu, \mu_{i}, \gamma_{1} \gamma_{i}, \beta=\left(\beta_{i 1}, \ldots, \beta_{i m}\right)$ are true parameters. $D_{i, t}$ takes as value of 1 if $t>T_{B i}(i=1, \ldots, k)$ and of 0 otherwise, where $k$ is the maximum number of breaks and $T_{B i}$ denotes the time period of the break.

The asymptotic critical values of the tests for the maximum number of breaks (from 1 to 5) approximated by Monte Carlo simulations coded by GAUSS are given in Maki (2012). The null hypothesis of non-existence of co-integration between series is rejected in case of calculated test statistics being smaller than these critical values. In other words, calculated test statistics being smaller than critical values point out that alternative hypothesis of existence of co-integration between the series under multiple structural breaks is accepted. According to the results of co-integration test of Maki (2012) given in Table 5, alternative hypothesis is accepted, concluding that the series are co-integrated in the long-run.

Table 5. Results of Maki (2012) Co-Integration tests

\begin{tabular}{cccccc}
\hline \multirow{2}{*}{ Models } & \multirow{2}{*}{ Test Statistics } & \multicolumn{3}{c}{ Critical Values } & \multirow{2}{*}{ Break Dates } \\
\cline { 3 - 5 } & & $1 \%$ & $5 \%$ & $10 \%$ & \\
\hline Model 0 & $-5.572^{* *}$ & -5.959 & -5.426 & -5.131 & 1999.Q2; 2001.Q2; 2003.Q3; 2005.Q2; 2010.Q1 \\
Model 1 & $-6.835^{*}$ & -6.193 & -5.699 & -5.449 & 2000.Q4; 2002.Q3; 2004.Q2; 2007.Q1; 2008.Q3 \\
Model 2 & $-6.479^{* *}$ & -6.915 & -6.357 & -6.057 & 2001.Q3; 2004.Q4; 2006.Q1; 2008.Q3; 2010.Q4 \\
Model 3 & $-8.361^{*}$ & -8.004 & -7.414 & -7.110 & 2000.Q4; 2002.Q1; 2003.Q4; 2007.Q1; 2009.Q1 \\
\hline
\end{tabular}

Note. Critical values are obtained from the Table 1 in Maki (2012)'s study. * and ** denote significance levels of $1 \%$ and $5 \%$, respectively.

In the next step of the analysis, long-run parameters are to be estimated by Stock and Watson (1993) dynamic OLS method. Break dates obtained from co-integration test are also included in the model developed for parameter estimation.

\subsubsection{Long-Run Parameter Estimation by Stock and Watson (1993) Dynamic OLS Method}

The seminal work of Engle and Granger (1987) has led co-integration regressions to become one of the standard tools in analyzing integrated of order one, [I(1)] variables. The ordinary least squares (OLS) estimator is consistent in the presence of a serial correlation in the error term and/or a correlation between the regressors and co-integration errors. However, this estimator contains the so-called second-order bias problem. The fully 
modified OLS estimator by Phillips and Hansen (1990); canonical co-integrating regression estimator of Park (1992); and the dynamic OLS estimator of Phillips and Loretan (1991), Saikkonen (1991), and Stock and Watson (1993) are the typical estimators to overcome this problem. In this study, among these three estimators Stock and Watson (1993) dynamic OLS is used to estimate long-run parameters.

As a more robust method particularly in small samples, Stock and Watson (1993) dynamic OLS method can be applied irrespective of the order of integration of variables (irrespective of whether regressors are purely $\mathrm{I}(0)$, purely I(1), or mutually co-integrated); but the dependent variable needs to be $\mathrm{I}(1)$. The other predominant advantage of this method is that it provides strong and consistent estimations in the existence of internality and autocorrelation problems (Esteve \& Requena, 2006).

The DOLS estimator is obtained from the Equation (15):

$$
\mathrm{y}_{\mathrm{t}}=\alpha_{0}+\alpha_{1} \mathrm{t}+\alpha_{2} \mathrm{x}_{\mathrm{t}}+\sum_{\mathrm{i}=-\mathrm{q}}^{\mathrm{q}} \delta_{\mathrm{i}} \Delta \mathrm{x}_{\mathrm{t}-\mathrm{i}}+\varepsilon_{\mathrm{t}}
$$

where q represents optimum leads and lags, and $\varepsilon_{\mathrm{t}}$, error term, respectively.

The long-run parameters estimated by DOLS method given in Table 6 indicate the existence of statistically significant and positive relationship between profitability $(P R O F)$ and liquidity $(C U R)$. However, there is no statistically significant relationship between profitability $(P R O F)$ and growth $(G R O W)$ variables.

Table 6. DOLS Estimation results

\begin{tabular}{cccc}
\hline Variables & Coefficients & t-statistics & Prob. \\
\hline CUR & $0.038^{* *}$ & 1.955 & 0.062 \\
GROW & -0.098 & -1.529 & 0.139 \\
D1 & $-0.555^{* *}$ & -2.622 & 0.015 \\
D2 & $-0.252^{* *}$ & -2.475 & 0.020 \\
D3 & $-0.132^{* * *}$ & -1.780 & 0.099 \\
D4 & -0.121 & -0.780 & 0.443 \\
D5 & $0.253^{*}$ & 2.872 & 0.008 \\
$C$ & 0.098 & 1.544 & 0.136 \\
\hline
\end{tabular}

$\mathrm{R}^{2}=0.80$; D-W test statistics: 1.48 Note: $* * *$ and $* * *$ denote significance levels of $1 \%, 5 \%$ and $10 \%$ respectively.

\subsubsection{Bootstrap Causality Test of Hacker and Hatemi-J (2012)}

Co-integration analyses do not provide information on the direction of causality. Therefore, causality analysis should be undertaken in determining causal relationships between the series. This study uses bootstrap causality test suggested by Hacker and Hatemi-J (2012). In their previous study, Hacker and Hatemi-J (2006) have used Granger causality Wald test with a modification for integrated variables suggested in Toda and Yamamoto (1995). They conclude that this test is not appropriate to be used with relatively small sample sizes. Therefore, in 2012, they improved a new test by assuming the lag length to be unknown and the one chosen is data-driven; and focusing on smaller sample sizes (20-40 observations). The underlying idea behind their test is that positive and negative shocks may have different Granger-causal impacts.

In the context of Granger causality, Hacker and Hatemi-J (2012) consider the vector autoregressive model of order $k, \operatorname{VAR}(k)$ :

$$
\gamma_{t}=\beta_{0}+\beta_{1} \gamma_{t-1}+\cdots+\beta_{k} \gamma_{t-k}+\mu_{t}
$$

where $\gamma_{t}, \beta_{0}$ and $\mu_{t}$ are vectors with dimensions $n \times 1$ and $\beta_{i}, i \geq 1$ is a parameter matrix with $n \times n$ dimensions. The error vector, $\mu_{t}$, has a zero-expected value, assumed to be independent and identically distributed with a non-singular covariance matrix $\Omega$. The lag length, $k$, is determined by estimating the $V A R(k)$ model in Equation (16) for $k=0, \ldots, K$, where $K$ is the maximum lag length considered, and finding that $k$ which minimizes the information criterion suggested by Hatemi-J (2003-2008) as an alternative to Schwarz Bayesian Information Criterion $(S B C)$ and Akaike Information Criterion $(A I C)$. This alternate referred as Hatemi-J Information Criterion $(H J C)$ is as below:

$$
H J C=\ln \left(\operatorname{det} \widehat{\Omega}_{k}\right)+k\left(\frac{n^{2} \ln T+2 n^{2} \ln (\ln T)}{2 T}\right), k=0, \ldots, K
$$


where $\ln$ is the natural logarithm; $\operatorname{det} \widehat{\Omega}_{k}$ is the determinant of the estimated variance-covariance matrix of the residuals in the $\operatorname{VAR}(k)$ model for lag order $k ; n$ and $T$ are the number of variables and the sample size (number of observations), respectively.

In case of variables being integrated, standard asymptotical distributions cannot be used to test for restrictions in the VAR model. To overcome this problem, Toda and Yamamoto (1995) uses an augmented $V A R(k+d)$ model, where $d$ denotes integration order of variables. This model can be written compactly as below (Hatemi-J et al., 2006, p. 69):

$$
Y=D Z+\delta
$$

Toda and Yamamoto (1995)'s augmented $\operatorname{VAR}(k+d)$ model is as: $\gamma_{t}=\beta_{0}+\beta_{1} \gamma_{t-1}+\cdots+\beta_{k} \gamma_{t-k} \cdots+\beta_{k+d} \gamma_{t-k-d}+\mu_{t}$. Assuming that the initial values are given, the denotations in Hatemi-J et al. (2006) in order to represent the modified Wald statistics are as:

$Y:-\left(\gamma_{1}, \ldots, \gamma_{T}\right) \quad(n \times T)$ matrix,

$D:=\left(\beta_{0}, \beta_{1}, \ldots, \beta_{k}, \ldots, \beta_{k+d}\right) \quad(n \times 1(1+n(k+d)))$ matrix,

$Z_{t}:=\left[\begin{array}{c}1 \\ \gamma_{t} \\ \gamma_{t-1} \\ \vdots \\ \gamma_{t-k-d+1}\end{array}\right]((1+n(k+d)) \times 1)$ matrix, for $t=1, \ldots, T$

$Z:=\left(Z_{0}, \ldots, Z_{t-1}\right) \quad((1+n(k+d)) \times T)$ matrix, and

$\delta:=\left(e_{1}, \ldots, e_{T}\right) \quad(n \times T)$ matrix.

To test the null hypothesis of non-Granger causality, the modified Wald (MWALD) test statistic is used. This test is as:

$$
M W A L D=(Q \hat{\beta})^{\prime}\left[Q\left(\left(\mathrm{Z}^{\prime} \mathrm{Z}\right)^{-1} \Theta \Omega_{U}\right) Q^{\prime}\right]^{-1}(Q \hat{\beta}) \sim \chi_{k}^{2}
$$

where $Q$ is an $k \times n(1+n(k+d))$ indicator matrix used to identify restrictions implied by the null hypothesis; and $\Theta$ is the element by all element matrix multiplication operator (the Kronecker product. $\Omega_{U}$ is the estimated variance-covariance matrix of residuals in Equation (18) when the restrictions implied by the null hypothesis of non-Granger causality is not imposed and is determined by the formula $\Omega_{U}=\left(\delta_{U} \delta \delta_{U}^{\prime}\right) \div(T-(1+n k))$, where $(1+n k)$ is the number of parameters.

Under the normal distribution assumption, the Wald test statistics follows a $\chi^{2}$ distribution with $k$ degrees of freedom asymptotically. However, in cases where sample size is relatively small; the error terms are not normally distributed; and autoregressive conditional heteroscedasticity effects exist, asymptotic critical values of the Wald test are not precise. For the solution of this problem, Hacker and Hatemi-J (2012) have suggested a test based on leveraged bootstrap simulations emphasizing that when the lag length choice is endogenized, the suggested test will perform better with more precise results. The null hypothesis non-Granger causality is rejected in case of calculated Wald statistic being higher than the bootstrap critical value. Causality test results (given in Table 7) do not indicate any direction of causality between the series.

\begin{tabular}{|c|c|c|c|c|}
\hline \multirow{2}{*}{ The Null Hypothesis } & \multirow{2}{*}{ MWALD Statistics } & \multicolumn{3}{|c|}{ Critical Values } \\
\hline & & $1 \%$ & $5 \%$ & $10 \%$ \\
\hline No Causality from $R O A$ to $C U R$ & 0.118 & 7.191 & 4.119 & 2.841 \\
\hline No Causality from $C U R$ to $R O A$ & 1.535 & 7.326 & 4.101 & 2.860 \\
\hline No Causality from $R O A$ to $G R O W$ & 0.057 & 7.071 & 4.082 & 2.830 \\
\hline No Causality from $G R O W$ to $R O A$ & 0.055 & 7.258 & 4.100 & 2.809 \\
\hline No Causality from $C U R$ to $G R O W$ & 0.063 & 7.276 & 3.992 & 2.779 \\
\hline No Causality from $G R O W$ to $C U R$ & 0.040 & 7.269 & 3.902 & 2.739 \\
\hline
\end{tabular}

Table 7. Bootstrap Causality test of Hacker and Hatemi-J (2012)

Note. *, ** and $* * *$ denote significance levels of $1 \%, 5 \%$ and $10 \%$. The bootstrapping is repeated 10,000 times.

\section{Conclusion}

This study investigates the relationship between profitability and liquidity in Turkish retail industry. In the study, some advanced econometric tools such as the unit root test of Carrioni-i-Silvestre et. al. (2009), the 
co-integration test of Maki (2012), Stock and Watson (1993) dynamic OLS method, and Hacker and Hatemi-J (2012) bootstrap causality test are used. This is the main contribution of this study to the literature, as these tools have not been used in analyzing the profitability-liquidity relationship before.

Firstly, the stationarity of series is tested by unit root test of Carrioni-i-Silvestre et. al. (2009). The structural break dates estimated by this test point out dramatic turning points in Turkish economy. Beginning from the mid-1980s, Turkey's remarkable transformation due to the liberalization process has prepared a base for the enormous development of retail industry in Turkey. However, as this process has not been sufficiently supported by sound macroeconomic policies, and regulatory and institutional reforms, Turkish economy (and, of course, Turkish retail industry) has witnessed several crises. Over the entire sample period, in 1999, 2000, 2001, and 2007-2008, both financial and economic crises hit the Turkish economy, and the entire retail industry. Following the 1997-1998 East Asian economic crisis, and Marmara and Bolu earthquakes on August 17th and November 12th, 1999, Turkish economy entered into a deep financial and economic crisis period in 1999, hitting the bottom in 2001. Then, along with the world economy, Turkish economy faced with the financial crisis of 2007-08 (also known as 2008 Financial Crisis). These crises have not only influenced major manufacturing industries, but also retail industry as well. Following the 2008 financial crisis, the manufacturing industry was contracted by $10.8 \%$ and annual growth rate of organized retail sector was record low in 2009. Due to reflections of the crisis in the market, consumers' opinions on current conditions and future expectations of the economy were negative.

Co-integration relationship and co-integration coefficients between the series (profitability, liquidity and growth) are tested by co-integration test of Maki (2012) and Stock and Watson (1993)'s dynamic OLS method, respectively. The results of Maki (2012) test indicate that the series are co-integrated in the long-run. The long-run parameters estimated by DOLS indicate the existence of statistically significant and positive relationship between profitability and liquidity in Turkish retail industry. This finding is opposite to the theoretical argument that profitability and liquidity are generally assumed to be contradictory to each other, and also conflicts with the arguments of Fama and Jensen (1983), Myers and Rajan (1995), Adams (1996), Pottier (1998) and Adams and Buckle (2003) that higher liquidity may lead managers to make investments towards maximizing their own utility, thus to the detriment of profitability. However, this finding supports the conclusions of Deloof (2003) and Goddard et al. (2005). While Deloof (2003) concludes that higher liquidity enables firms to meet their short-term obligations easily without any additional cost, meaning increased profitability; Goddard et al. (2005) argues that higher liquidity allows firms to take advantage of profitable investment opportunities. Another empirical finding of the study is that there is no statistically significant relationship between profitability and growth (in sales) variables.

Finally, causal relationships between the variables are tested by Hacker and Hatemi (2012) bootstrap causality test. Test results do not indicate any direction of causality between the series.

Though this study contributes to the literature on the relationship between profitability and liquidity management for retail industry, it has some limitations. As this study focuses only on retail industry among other services industries, the findings may not directly be referred to other sub-sectors in services industry. Additionally, the focus of the study is on the financial aspect of liquidity management. The operational dimension of liquidity management in terms of cash conversion cycle and/or operating cycle is neglected. In further studies, the effect of liquidity on profitability in more diverse industries may be analyzed by focusing the operational dimension of liquidity management as well.

\section{References}

Adams, M. (1996). Investments earnings and the characteristics of life insurance firm: New Zealand evidence. Australian Journal of Management, 21(1), 41-55. http://dx.doi.org/10.1177/031289629602100106

Adams, M., \& Buckle, M. (2003). The determinants of corporate financial performance in the Bermuda $\begin{array}{lllll}\text { insurance market. Applied } & \text { Financial }\end{array}$ http://dx.doi.org/10.1080/09603100210105030

Afeef, M. (2011). Analyzing the impact of working capital management on the profitability of SME's in Pakistan. International Journal of Business and Social Science, 2(22), 173-183.

Afonina, A., \& Chalupsky, V. (2014). The performance of high-tech companies: The evidence from the Visegrad Group. Central European Review of Economic Issues, 17, 181-197. http://dx.doi.org/10.7327/cerei.2014.12.03

Alavinasab, S. M., \& Davoudi, E. (2013). Studying the relationship between working capital management and profitability of listed companies in Tehran Stock Exchange. Business Management Dynamics, 2(7), 1-8. 
Al-Matari, E. M., Al-Swidi, A. K., \& Fadzil, F. H. (2014). The measurements of firm performance's dimensions. Asian Journal of Finance and Accounting, 6(1), 24-49. http://dx.doi.org/10.5296/ajfa.v6i1.4761

Amato, L., \& Amato, C. (2004). Firm size, strategic advantage, and profit rates in US retailing. Journal of Retailing and Consumer Services, 11(3), 181-193. http://dx.doi.org/10.1016/S0969-6989(03)00036-5

Bain, J. B. (1959). Industrial Organization. NY, USA: John Wiley \& Sons Publications.

Ball, R., \& Watts, R. (1972). Some time series properties of accounting income. Journal of Finance, 27(3), 663-681. http://dx.doi.org/10.1111/j.1540-6261.1972.tb00991.x

Banos-Caballero, S., Garcia-Teruel, P. J., \& Martinez-Solano, P. (2014). Working capital management, corporate performance, and financial constraints. Journal of Business Research, 67(3), 332-338. http://dx.doi.org/10.1016/j.jbusres.2013.01.016

Bardia, S. C. (2004). Liquidity management: A case study of steel authority of India Ltd. The Management Accountant, 463-467.

Barney, J. (1991). Firm resources and sustained competitive advantage. Journal of Management, 17(1), 99-120. http://dx.doi.org/10.1177/014920639101700108

Barney, J. (2001). Resource-based theories of competitive advantage: A ten-year retrospective on the resource based view. Journal of Management, 27(6), 643-650. http://dx.doi.org/10.1177/014920630102700602

Bhayani, S. J. (2010). Determinant of profitability in Indian cement industry: An economic analysis. South Asian Journal of Management, 17(4), 6-20.

Bokhari, H. W., \& Khan, M. A. (2013). The impact of capital structure on firm's performance: A case of non-financial sector of Pakistan. European Journal of Business and Management, 5(31), 111-137.

Bottazzi, G., Dosi, G., Jacoby, N., Secchi, A., \& Tamagni, F. (2010). Corporate performances and market selection: Some comparative evidence. Industrial and Corporate Change, 19, 1953-1996. http://dx.doi.org/10.1093/icc/dtq063

Callen, J., Cheung, C., Kwan, C., \& Yip, R. (1993). An empirical investigation of the random character of annual earnings. Journal of Accounting, Auditing and Finance, 8(2), 151-162. http://dx.doi.org/10.1177/0148558X9300800204

Capon, N., Farley, J. U., \& Hoenig, S. (1990). Determinants of financial performance: A meta-analysis. Management Science, 36(10), 1143-1159. http://dx.doi.org/10.1287/mnsc.36.10.1143

Carrioni-i-Silvestre, J. L., \& Sanso, A. (2006). Testing the null of cointegration with structural breaks. Oxford Bulletin of Economics and Statistics, 68, 623-646. http://dx.doi.org/10.1111/j.1468-0084.2006.00180.x

Carrioni-i-Silvestre, J. L., Kim, D., \& Perron, P. (2009). GLS-based unit root tests with multiple structural breaks under both the null and the alternative hypothesis. Econometric Theory, 25(Special Issue 6), 1754-1792. http://dx.doi.org/10.1017/S0266466609990326

Chan, L. K. C., Karceski, J., \& Lakonishok, J. (2003). The level and persistence of growth rates. Journal of Finance, 58(2), 643-684. http://dx.doi.org/10.1111/1540-6261.00540

Churchill, N. C., \& Mullins J. W. (2001). How fast can your company afford to grow? Harvard Business Review, 79(5), 165-142.

Coad, A. (2007). Testing the principle of "growth of the fitter": The relationship between profits and firm growth. Structural Change and Economic Dynamics, 18, 370-386. http://dx.doi.org/10.1016/j.strueco.2007.05.001

Daft, R. L. (1983). Organization Theory and Design. New York, USA: West Publishing.

Deloitte. (2014). Retail Sector Update. July.

Deloof, M. (2003). Does working capital management affect profitability of Belgian firms? Journal of Business, Finance and Accounting, 30(3-4), 573-588. http://dx.doi.org/10.1111/1468-5957.00008

Demirgüneş, K., \& Üçler, G. (2015). Inter-relationship between profitability, growth and size: Case of Turkey. Journal of Economics, Business and Finance, 4(4), 659-678. http://dx.doi.org/10.17261/Pressacademia.2015414534

Dong, H. P., \& Su, J. T. (2010). The relationship between working capital management and profitability: A Vietnam case. International Research Journal of Finance and Economics, 49, 60-71. 
Ebaid, I. E. (2009). The impact of capital structure choice on firm performance: Empirical evidence from Egypt. Journal of Risk Finance, 10(5), 477-487. http://dx.doi.org/10.1108/15265940911001385

Ehiedu, V. C. (2014). The impact of liquidity on profitability of some selected companies: The financial statement analysis (FSA) approach. Research Journal of Finance and Accounting, 5(5), 81-90.

Eljelly, A. M. A. (2004). Liquidity-profitability trade-off: An empirical investigation in an emerging market. International Journal of Commerce and Management, 14(2), 48-61. http://dx.doi.org/10.1108/10569210480000179

Elliot, G., Rothenberg, T. J., \& Stock, J. H. (1996). Efficient tests for an autoregressive time series with a unit root. Econometrica, 64(4), 813-836. http://dx.doi.org/10.2307/2171846

Engle, R. F., \& Granger, C. W. J. (1987). Cointegration and error correction: Representation, estimation, and testing. Econometrica, 55, 251-276. http://dx.doi.org/10.2307/1913236

Erdil. A., Erdil, M., \& Erbiyık, H. (2014). A case study about retailing market of industrial sector in Turkey. Proceedings of the 2014 International Conference on Industrial Engineering and Operations Management, January, 7-9, Bali, Indonesia.

Erkip, F. (2005). The rise of the shopping mall in Turkey: The use and appeal of a mall in Ankara. Cities, 22(2), 89-108. http://dx.doi.org/10.1016/j.cities.2004.10.001

Erkip, F., \& Özüduru, B. H. (2015). Retail development in Turkey: An account after two decades of shopping malls in the urban scene. Progress in Planning, 102, 1-33. http://dx.doi.org/10.1016/j.progress.2014.07.001

Esteve, V., \& Requena, F. (2006). A cointegration analysis of car advertising and sales data in the presence of structural change. International Journal of the Economics of Business, 13, 111-128. http://dx.doi.org/10.1080/13571510500520036

Fama, E., \& French, K. (2002). The equity premium. The Journal of Finance, 57(2), 161-178. http://dx.doi.org/10.1111/1540-6261.00437

Fama, E., \& Jensen, M. (1983). Agency problems and residual claims. Journal of Law and Economics, 26(2), 327-349. http://dx.doi.org/10.1086/467038

Farris II, M. T., \& Hutchison P. D. (2002). Cash-to-cash: The new supply chain management metric. International Journal of Physical Distribution and Logistics Management, 32(4), 288-298. http://dx.doi.org/10.1108/09600030210430651

Ferati, R., \& Ejupi, E. (2012). Capital structure and profitability: The Macedonian case. European Scientific Journal, 8(7), 51-58.

Galbreath, J., \& Galvin, P. (2008). Firms factors, industry structure and performance variation: New empirical evidence to a classic debate. Journal of Business Research, 61(2), 109-117. http://dx.doi.org/10.1016/j.jbusres.2007.06.009

Garcia-Teruel, P. J., \& Martinez-Solano, P. (2007). Effects of working capital management on SME profitability. $\begin{array}{lllll}\text { International Journal of } & \text { Managerial }\end{array}$ http://dx.doi.org/10.1108/17439130710738718

Ghosh, S. K., \& Maji, S. G. (2003). Utilization of current assets and operating profitability: An empirical study on cement and tea industries in India. Indian Journal of Accounting, IAA, 81-91.

Gilbert, D. (2003). Retail Marketing Management (2nd ed.). New York, USA: Prentice Hall Publications.

Gill, A., Biger, N., \& Mathur, N. (2010). The relationship between working capital management and profitability: Evidence from the United States. Business and Economics Journal, BEJ-10, 1-9.

Goddard, J., Tavakoli, M., \& Wilson, J. O. S. (2005). Determinants of profitability in European manufacturing and services: Evidence from a dynamic panel model. Applied Financial Economics, 15(18), 1269-1282. http://dx.doi.org/10.1080/09603100500387139

Gombola, M. J., \& Ketz, J. E. (1983). Financial ratio patterns in retail and manufacturing organizations. Financial Management, 7(1), 45-56. http://dx.doi.org/10.2307/3665210

Gregory, A. W., \& Hansen, B. E. (1996). Tests for cointegration in models with regime and trend shifts. Oxford $\begin{array}{lllll}\text { Bulletin of } \quad \text { Economics } & \text { 5tatistics, } & \text { 58, } & \text { 55-560. }\end{array}$ http://dx.doi.org/10.1111/j.1468-0084.1996.mp58003008.x 
Hacker, S., \& Hatemi, J. A. (2006). Test for causality between integrated variables using asymptotic and bootstrap distributions: Theory and application. Applied Economics, 38, 1489-1500. http://dx.doi.org/10.1080/00036840500405763

Hacker, S., \& Hatemi, J. A. (2012). A bootstrap test for causality with endogenous lag length choice: Theory and

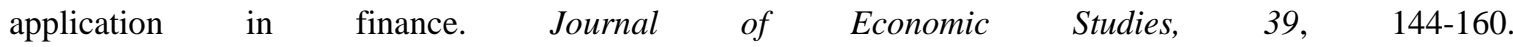
http://dx.doi.org/10.1108/01443581211222635

Harrison, T. S. (1994). Mapping customer segments for personal financial services. International Journal of Bank Marketing, 12(8), 17-25. http://dx.doi.org/10.1108/02652329410069010

Hatemi, J. A. (2003). A new method to choose optimal lag order in stable and unstable VAR models. Applied Economics Letters, 10, 135-137. http://dx.doi.org/10.1080/1350485022000041050

Hatemi, J. A. (2008). Tests for cointegration with two unknown regime shifts with an application to financial market integration. Empirical Economics, 35, 497-505. http://dx.doi.org/10.1007/s00181-007-0175-9

Hatemi, J. A., Roca, E., \& Buncic, D. (2006). Bootstrap causality tests of the relationship between the equity markets of the US and other developed countries: Pre- and post-September 11. Journal of Applied Business Research, 22, 65-74. http://dx.doi.org/10.19030/jabr.v22i3.1427

Jang, S., \& Park, S. (2011). Inter-relationship between firm growth and profitability. International Journal of Hospitality Management, 30, 1027-1035. http://dx.doi.org/10.1016/j.ijhm.2011.03.009

Jensen, M. (1986). Agency costs of free cash flow, corporate finance and takeover. American Economic Review: Papers and Proceedings, 76(2), 323-329. http://dx.doi.org/10.2139/ssrn.99580

Jose, M. L., Lancaster, C., \& Stevens, J. L. (1996). Corporate returns and cash conversion cycles. Journal of Economics and Finance, 20(1), 33-46. http://dx.doi.org/10.1007/BF02920497

Kamath, R. (1989). How useful are common liquidity measures? Journal of Cash Management, January/February, 24-28.

Katırcığlu, S. T. (2014). Testing the tourism-induced EKC hypothesis. Economic Modelling, 41, 383-391. http://dx.doi.org/10.1016/j.econmod.2014.05.028

Kaya, H. (2014). Are retailers more sensitive to changes in business conditions compared to wholesalers?. International Journal of Business and Social Science, 5(10-1), 1-8.

Kaynak, E. (1986). Marketing and Economic Development. New York, USA: Praeger.

Khaldun, K. I., \& Muda, I. (2014). The influence of profitability and liquidity ratios on the growth of profit of manufacturing companies: A study of food and beverages sector companies listed on Indonesia Stock Exchange (period 2010-2012). International Journal of Economics, Commerce and Management, 2(12), $1-17$.

Kim, D., \& Perron, P. (2009). Unit root tests allowing for a break in the trend function at an unknown time under both the null and alternative hypothesis. Journal of Econometrics, 148, 1-13. http://dx.doi.org/10.1016/j.jeconom.2008.08.019

Kroes, J. R., \& Manikas, A. S. (2014). Cash flow management and manufacturing firm financial performance: A longitudinal perspective. International Journal of Production Economics, 148, 37-50. http://dx.doi.org/10.1016/j.ijpe.2013.11.008

Kumcu, E., \& Kumcu, M. E. (1987). Determinants of food retailing in developing economies: The case of Turkey. Journal of Macromarketing, 7(2) 26-40. http://dx.doi.org/10.1177/027614678700700205

Little, I. (1962). Higgledy-piggledy growth. Bulletin of the Oxford University Institute of Economics and Statistics, 24(4), 387-412. http://dx.doi.org/10.1111/j.1468-0084.1962.mp24004001.x

Lyroudi, K., Mc Carty D., Lazaridis, J., \& Chatzigagios, T. (1999, October). An Empirical Investigation of Liquidity: The Case of UK Firms. Paper presented at the Annual Financial Management Association Meeting in Orlando.

Maki, D. (2012). Tests for cointegration allowing for an unknown number of breaks. Economic Modelling, 29, 2011-2015. http://dx.doi.org/10.1016/j.econmod.2012.04.022

McKechnie, S. (1992). Consumer buying behavior in financial services: An overview. International Journal of Bank Marketing, 5, 4-12. http://dx.doi.org/10.1108/02652329210016803 
McKechnie, S., \& Harrison, T. (1995). Understanding consumers and markets In C. Ennew, T. Watkins, \& M. Wright (Eds.), Marketing Financial Services (2nd ed.). Oxford: Butterworth-Heinemann.

Meder Çakır, H., \& Küçükkaplan, İ. (2009). Analyzing effects of working capital components on profitability and valuation of manufacturing firms in ISE for 2000-2009 period. Journal of Accounting and Finance, 53, 69-86.

Muhammad, M., Jan, W. U., \& Ullah K. (2012). Working capital management and profitability: An analysis of firms of textile industry of Pakistan. Journal of Managerial Sciences, 6(2), 155-165.

Mun, S. G., \& Jang, S. (2015). Working capital, cash holding, and profitability of restaurant firms. International Journal of Hospitality Management, 48, 1-11. http://dx.doi.org/10.1016/j.ijhm.2015.04.003

Myers, S., \& Rajan, R. G. (1995). The paradox of liquidity. Working Paper W5143. Cambridge, MA: National Bureau of Economic Research.

Narware, P. C. (2004). Working capital and profitability - An empirical analysis. The Management Accountant, 39(6), 279-300.

Ng, S., \& Perron, P. (2001). Lag length selection and the construction of unit root tests with good size and power. Econometrica, 69, 1519-1554. http://dx.doi.org/10.1111/1468-0262.00256

Niresh, J. A. (2012). Trade-off between liquidity and profitability: A study of selected manufacturing firms in Sri Lanka. Journal of Arts, Science and Commerce, 4(2), 34-40.

Nunes, P. M., Serrasqueiro, Z. M., \& Sequeira, T. N. (2009). Profitability in Portuguese service industries: A panel data approach. The Service Industries Journal, 29(5), 693-707. http://dx.doi.org/10.1080/02642060902720188

Nunes, P. M., Serrasqueiro, Z. S., \& Leitao, J. (2010). Are there nonlinear relationships between the profitability of Portuguese service SME and its specific determinants? The Service Industries Journal, 30(8), 1313-1341. http://dx.doi.org/10.1080/02642060802398853

OECD (Organization for Economic Co-operation and Development). Factbooks, (1990-2015).

Özcan, G. B. (2000). The transformation of Turkish retailing: Survival strategies of small and medium-sized retailers. Journal of Southern Europe and the Balkans, 2(1), 105-120. http://dx.doi.org/10.1080/14613190050004862

Özçelik, H., \& Kandemir, B. (2015). The evaluation of the financial performances of the tourism enterprises traded on BIST with TOPSIS method. Ballkesir University The Journal of Social Sciences Institute, 18(33), 97-114.

Panigrahi, A. K. (2014). Relationship of working capital with liquidity, profitability and solvency: A case study of ACC Limited. Asian Journal of Management Research, 4(2), 308-322.

Park, Y. J. (1992). Canonical cointegrating regressions. Econometrica, 60, 119-143. http://dx.doi.org/10.2307/2951679

Pattitoni, P., Petracci, B., \& Spisni, M. (2014). Determinants of profitability in the EU-15 area. Applied Financial Economics, 24(11), 763-775. http://dx.doi.org/10.1080/09603107.2014.904488

Perron, P. (1989). The Great Crash, the oil price shock, and the unit root hypothesis. Econometrica Journal of the Econometric Society, 1361-1401. http://dx.doi.org/10.2307/1913712

Perron, P., \& Ng, S. (1998). An autoregressive spectral density estimator at frequency zero for nonstationarity tests. Econometric Theory, 14, 560-603. http://dx.doi.org/10.1017/S0266466698145024

Perron, P., \& Qu, Z. (2007). A simple modification to improve the finite sample properties of $\mathrm{Ng}$ and Perron's unit root tests. Economics Letters, 94, 12-19. http://dx.doi.org/10.1016/j.econlet.2006.06.009

Perron, P., \& Rodriguez, G. (2003). GLS detrending efficient unit root tests and structural change. Journal of Econometrics, 115, 1-27. http://dx.doi.org/10.1016/S0304-4076(03)00090-3

Phillips, P. C. B., \& Hansen, B. E. (1990). Statistical inference in instrumental variables regression with I(1) processes. Review of Economic Studies, 57, 99-125. http://dx.doi.org/10.2307/2297545

Phillips, P. C. B., \& Loretan, M. (1991). Estimating long-run economic equilibria. Review of Economic Studies, 58, 407-436. http://dx.doi.org/10.2307/2298004 
Phillips, P., \& Sipahioglu, M. (2004). Performance implications of capital structure: Evidence from quoted UK organizations with hotel interests. The Service Industries Journal, 24(5), 31-51. http://dx.doi.org/10.1080/0264206042000276829

Pottier, S. (1998). Life insurer financial distress, best's ratings and financial ratios. The Journal of Risk and Insurance, 65(2), 275-278. http://dx.doi.org/10.2307/253536

Randall, W. S., \& Farris II, M. T. (2009). Supply chain financing: Using cash-to-cash variables to strengthen the supply chain. International Journal of Physical Distribution and Materials Management, 39(8), 669-689. http://dx.doi.org/10.1108/09600030910996314

Rehman, M. Z., Khan M. N., \& Khokhar, I. (2015). Investigating liquidity-profitability relationship: Evidence from companies listed in Saudi Stock Exchange. Journal of Applied Finance and Banking, 5(3), 159-173.

Saikkonen, P. (1991). Asymptotically efficient estimation of cointegration regressions. Econometric Theory, 7 , 1-21. http://dx.doi.org/10.1017/S0266466600004217

Saldanl1, A. (2012). The relationship between liquidity and profitability - An empirical study on the ISE100 manufacturing sector. Journal of Süleyman Demirel University Institute of Social Sciences, 2(16), 167-176.

Şamiloğlu, F., \& Demirgüneş, K. (2008). The effect of working capital management on firm profitability: Evidence from Turkey. The International Journal of Applied Economics and Finance, 2, 44-50. http://dx.doi.org/10.3923/ijaef.2008.44.50

Shin, H. H., \& Soenen, L. (1998). Efficiency of working capital management and corporate profitability. Financial Practice and Education, 8(2), 37-45.

Short, J. C., McKelvie, A., Ketchen, D. J., \& Chandler, G. N. (2009). Firm and industry effects on performance: A generalization and extension for new ventures. Strategic Entrepreneurship Journal, 3, 47-65. http://dx.doi.org/10.1002/sej.53

Singh, J. P., \& Pandey, S. (2008). Impact of working capital management in the profitability of Hindalco Industries Limited. Journal of Financial Economics, 6(4), 62-72.

Sinku, S. (2015). Impact of liquidity management on profitability performance of steel authority of India Limited. Journal of Poverty, Investment and Development, 7, 36-41.

Stock, J. H. (1999). A class of tests for integration and cointegration In W. J. Granger (Ed.), Cointegration, Causality, and Forecasting: A Festschrift for Clive (pp. 135-167). Oxford University Press.

Stock, J. H., \& Watson, M. W. (1993). A simple estimator of cointegrating vectors in higher order integrated systems. Econometrica, 61, 783-820. http://dx.doi.org/10.2307/2951763

Stulz, R. (1990). Managerial discretion and optimal financing policies. Journal of Financial Economics, 26(1), 3-27. http://dx.doi.org/10.1016/0304-405X(90)90011-N

Sur, D., \& Chakraborty, K. (2011). Evaluating relationship of working capital and profitability: A study of selected multinational companies in the Indian pharmaceutical sector. Journal of Management Research, $10(2), 7-22$.

Sur, D., Biswas, J., \& Ganguly, P. (2001). Liquidity management in Indian private sector enterprises: A case study of Indian primary aluminum producing industry. Indian Journal of Accounting, 8-14.

The Economist Intelligence Unit (EIU). (2014). Turkey Consumer Goods Reports.

The World Bank Databases. (1990-2015).

Toda, H. Y., \& Yamamoto, T. (1995). Statistical inference in vector autoregressions with possibly integrated processes. Journal of Econometrics, 66, 225-250. http://dx.doi.org/10.1016/0304-4076(94)01616-8

Tokatl1, N., \& Boyac1, Y. (1998). The changing retail industry and retail landscapes: The case of post-1980 Turkey. Cities, 15(5), 345-359. http://dx.doi.org/10.1016/S0264-2751(98)00030-4

Topal, B., Tunahan, H., \& Dizkırıcı, A. S. (2013). Analyzing the working capital structure and profitability of supermarket chains: An evidence from Istanbul Stock Exchange Trade Index. The Journal of Business Science, 1(1), 57-69.

TUIK (Turkish Statistical Institute) Databases (1990-2015).

UNDP (United Nations Development Programme). Human Development Reports (1990-2015). 
Velnampy, T., \& Niresh, J. A. (2012). The relationship between capital structure and profitability. Global Journal of Management and Business Research, 12, 67-73.

Wang, Y. J. (2002). Liquidity management, operating performance, and corporate value: Evidence from Japan and Taiwan. Journal of Multinational Financial Management, 12(2), 159-169. http://dx.doi.org/10.1016/S1042-444X(01)00047-0

Weinzimmer, L. G., Nystrom, P. C., \& Freeman, S. J. (1998). Measuring organizational growth: Issues, consequences and guidelines. Journal of Management, 24, 235-262. http://dx.doi.org/10.1177/014920639802400205

Wernerfelt, B. (1984). A Resource-based view of the firm. Strategic Management Journal, 5(2), 171-180. http://dx.doi.org/10.1002/smj.4250050207

Westerlund, J., \& Edgerton, D. (2006). New improved tests for cointegration with structural breaks. Journal of Time Series Analysis, 28(2), 188-224. http://dx.doi.org/10.1111/j.1467-9892.2006.00504.x

Zivot, E., \& Andrews, D. W. K. (2002). Further evidence on the Great Cash, the oil price shock, and the unit root test. Journal of Business and Economic Statistics, 20(1), 25-44. http://dx.doi.org/10.1198/073500102753410372

\section{Note}

Note 1. "Financial services industry" (which encompasses a broad range of businesses that manage money, including credit unions, banks, credit-card companies, insurance companies, consumer-finance companies, stock brokerages, investment funds and some government-sponsored enterprises, etc.) forming a part of the wider "services industry" is not analyzed in this study. It can be said that some distinctive characteristics of financial services industry differs it from other service industries such as tradesmanship (like mechanic or plumber services), computer services, restaurants, tourism, etc. McKechnie (1992) defines these distinctive characteristics which are unique to financial services industry as fiduciary responsibility and two-way information flows. Fiduciary responsibility is defined as "the implicit responsibility of financial service organizations for the management of their customers' funds and the nature of financial advice supplied to customers" (McKechnie \& Harrison, 1995). Two-way information flows concept means that financial services should not be evaluated with one-off purchases but involves regular two-way transactions over an extended time period (Harrison, 1994).

\section{Copyrights}

Copyright for this article is retained by the author(s), with first publication rights granted to the journal.

This is an open-access article distributed under the terms and conditions of the Creative Commons Attribution license (http://creativecommons.org/licenses/by/3.0/). 